\title{
Incremental change, rather than wholesale reform, expected from new US president Barack Obama
}

I $\mathrm{t}$ is election day in Chicago, Illinois, and Harold Jackson, 63, sits on a park bench in Hyde Park just a few minutes' walk from Barack Obama's home - surveying those who have shown up in swarms to cast their ballots.

As the sun glints through the trees, Jackson speaks about his recent bout with testicular cancer. He was lucky. He was insured, though poorly, through his work as a truck driver. And although insurance covered most of his treatment, it didn't cover expensive anti-nausea drugs that he needed.

"I just had to take it," he says softly. "I still had it better than most. Others have it far worse. Our health care system is broken."

He pauses.

"Something has to change."

After Obama is elected the 44th President of the United States later that evening, there is little doubt that something will indeed change, though the speed of that change is debatable.

On the surface, with the Democrats controlling the White House, the Senate and Congress as of Jan. 21, it seems America is in for an era of major health care reform. But the reality is that Obama's actual health plans are quite modest compared to the high hopes of many.

Reform, he says, must build "upon the strengths of the US health care system." The main cornerstones of his plan include expanding Medicaid, to allow more uninsured people access, and making health insurance mandatory for children. For the uninsured, a program would be created whereby they could purchase a public or private policy. The plan would also funnel more monies into subsidizing health insurance for low-income Americans and those employed by small businesses. Medium to large businesses would get dinged on their taxes for failing to provide employees with health insurance.

Obama has broken his plan into 3 parts: "quality, affordable and portable health coverage for all;" modernization of the health care system; and "pro-

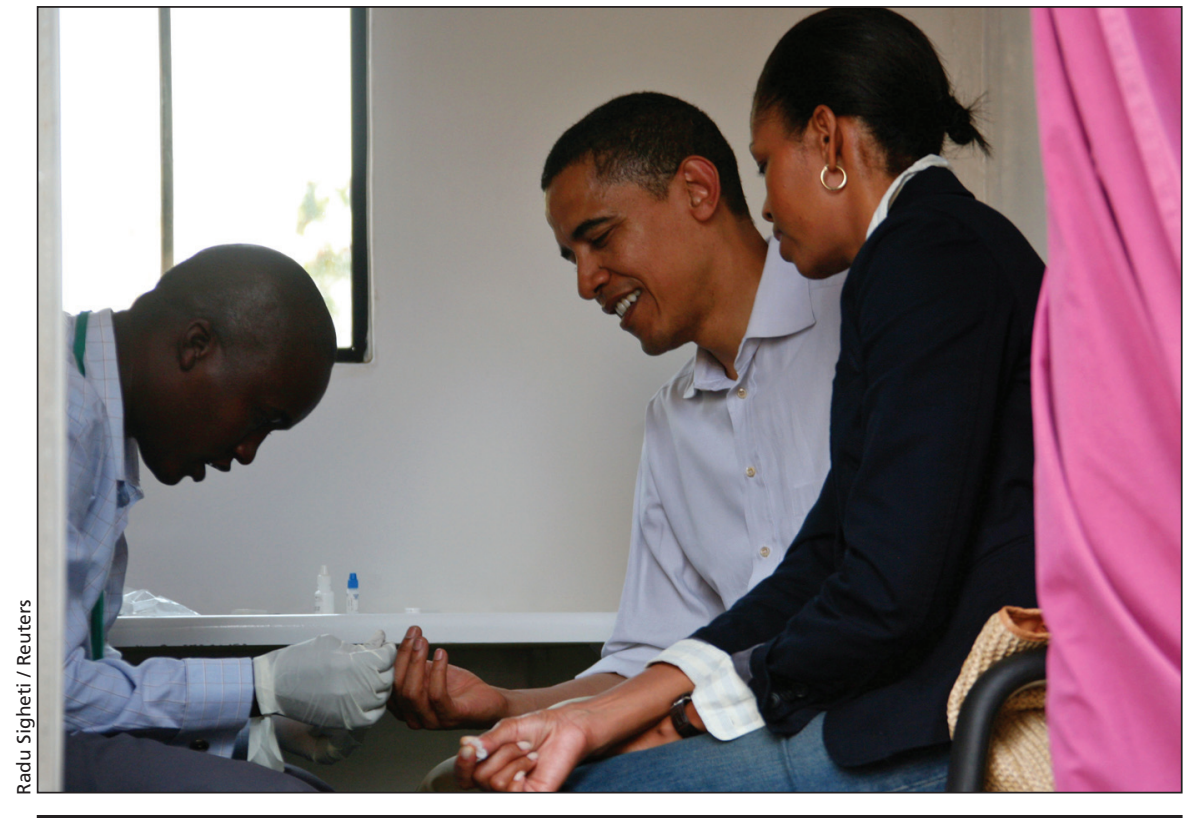

US President-Elect Barack Obama and his wife, Michelle, take an HIV-AIDS test inside a mobile clinic in Kisumu, Kenya, as part of a bid to reduce the stigma associated with testing.

moting prevention and strengthening public health."

He estimates it will save the average American family $\$ 2500$ annually. But while the plan would slash the number of uninsured Americans, it won't mandate that all adults in the US have insurance.

How it will be rolled out remains a mystery.

The price tag, though, could be staggering. An independent analysis of Obama's plan, conducted by the Lewin Group, a nonpartisan health care policy research firm in Falls Church, Virginia, found that it would decrease the number of uninsured by 26.6 million to 22.3 million by early 2010 . The firm estimated that implementation would cost US\$1.17 trillion from 2010 through 2019 , with an annual cost anywhere between $\$ 60$ billion and $\$ 100$ billion. Overall US health care spending in 2010 would be $\$ 2.7$ trillion.

Those are daunting numbers, experts say. "If history is any guide, things are going to move really slowly in the US," says Frank Sloan, J. Alexander McMahon professor of health policy and management, and professor of economics at Duke Uni- versity in Durham, North Carolina. "Unless he's willing to spend a lot of capital on this, it's going to be hard. The realism will come now."

Sloan, like many, expects the US financial crisis will put the brakes on health system reform. Although polls indicate that health care ranks near the top of American concerns - alongside terrorism, energy and war - the economy trumps all.

"Most people are reasonably happy with what they have," with respect to health care, he says. "They're not going to be happy - especially with the financial crisis - with paying for the burden."

Americans also appear culturally opposed to government solutions, adds Dr. Michael Rachlis, a Toronto-based health policy analyst.

"There is such an overall antigovernment bias and a lack of trust in government to deliver services," he says. "It's going to require a massive economic disaster, like the Great Depression, to get Americans to change their opinion."

A universal, single-payer system, like that of Canada or Great Britain, simply isn't in the cards, even though the US could cut health administration 
costs by as much as one-third if it moved to such a system, Rachlis adds. "It's much cheaper to administer single-payer plans."

Still, many Obama supporters dream of such a system.

After watching her father's battle with cancer, Jackson's 21-year-old daughter, Elise, believes that time has come. "There is a huge portion of the population that is underinsured and uninsured," the nursing student says. "What kind of society do we live in if that's okay?"

Yet, even if universality isn't adopted, many believe some changes are inevitable.

Obama appears committed to importing more lower-cost generic drugs to the US, a move that's projected to save consumers $\$ 30$ billion while doubtless distressing brand-name pharmaceutical firms.

$\mathrm{He}$ is also proposing to authorize the federal government to negotiate bulk prescription-drug purchases for those on medicare. The measure was opposed by current President George Bush but has saved large pots of money for the US Veterans Health Administration.

Mandatory insurance for children also appears likely. It's widely anticipated that the State Children's Health Insurance Program, which was ratcheted down by Bush, will be significantly expanded to cover more children when it comes up for renewal in March. "It's the perfect place to start," because it has bipartisan support in Congress, says Rachlis.

Broader reform, though, is likely to come far more slowly, says Sloan. Until then, the US can be expected to spend far more on health care than Canada. In 2006, per-capita spending in Canada was US $\$ 3678$ as compared to a hefty $\$ 6714$ in the US, according to the Organisation for Economic Cooperation and Development.

"In Canada, you've got it," says Sloan. "Though it's a different political environment."

But for Jackson, change can't come fast enough. "I don't want anyone to go through what I had to," he says. "The question is how can we do that? How can we fix this broken system?" Katie Lewis, Chicago, Ill.

DOI:10.1503/cmaj.081870

\section{Ex-provincial health minister sees red}

$\mathrm{T}$ he rash is gone. The wrath, however, remains. Last fall, Jim Wilson, a former Ontario health minister, was asked to pay $\$ 125$ to make an appointment with his dermatologist to deal with a persistent rash under his arm.

The Conservative MPP (SimcoeGrey) bristled at the notion and told the dermatologist's receptionist that the charge was illegal. He asked her to remind the doctor "that I'm a former minister of health."

That argument had no effect. Wilson, in turn, declined to pay the $\$ 125$. Like millions of other Canadians, he doesn't have a family doctor. His retired about 4 years ago, and Wilson says he hasn't had time to line up for another.

When Wilson called the Ontario Ministry of Health about the charge, he was advised to obtain a referral letter from a walk-in clinic or emergency ward. He also called the College of Physicians and Surgeons of Ontario, though he didn't make a written complaint, which is necessary to trigger a formal investigation.

"I didn't want to embarrass the doctor," Wilson explained. "I just don't want people paying fees that are illegal ... I have elderly constituents who told me they would just pay the fee because they didn't know it was illegal."

Extra charges are increasingly being introduced at private clinics that offer publicly insured services (CMAJ 2008; 179[11]:1112-3), while advocacy groups report that more and more patients report concerns about physician charges (CMAJ 2008; 179[9]:888-9).

Wilson raised the issue in the Ontario legislature "on behalf of the 800000 to 1 million Ontarians who don't have a family doctor and can't get a legitimate

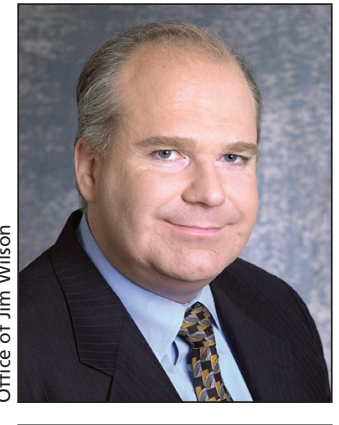

Conservative MPP Jim Wilson. done? "Physicians need to be reminded by the ministry ... probably through the CPSO [College of Physicians and Surgeons of Ontario], that the rules are the rules and if you are this hard up for money, come and talk to us - don't break the Canada Health Act."

The college declined to comment on Wilson's complaint, but a spokesperson says it will sometimes advise physicians if they are not in accord with college policy and will also refer information received about "aberrant billing" to the Ontario Health Insurance Plan. College policy (www.cpso.on.ca/policies/block fees.htm) states that "fees for being available to render an insured service" may not be charged.

Canadian Dermatology Association spokesperson and Toronto-based dermatologist Dr. Charles Lynde has heard of such fees being charged, particularly by doctors who also perform uninsured cosmetic procedures. The fee may be refunded if the visit turns out to be for an insured service, he adds. "It is a grey area ... every physician does what he thinks is right." Lynde says Wilson was " trying to queue jump" and should have "done what the rest of the world does and go see a walk-in clinic." Specialists in Ontario are paid less for an initial visit (a "consultation") if there is no referral letter, he added.

Under Ontario's 2005 Commitment to the Future of Medicare Act, the general manager of the health insurance plan is authorized to require doctors to submit information about extra charges to patients, including "unauthorized" payments. Violations have included charges for medical supplies, such as bandages and syringes, that are included as part of an insured physician service, letter." Health and Long-Term Care Minister David Caplan responded that "I find it remarkable that this member and his party, who advocated a $\$ 3$ billion cut to health care, would even deem to ask this question."

What does Wilson think ought to be and block fees that include some insured services.

The number of reported violations climbed to 320 in 2007/08 from 120 in 2004/05. — Ann Silversides, CMAJ

DOI:10.1503/cmaj.081872 